\title{
Apresentação a "Insânia loquaz" (Jobim, 1831) e a "Reflexões sobre o trânsito livre dos doidos pelas ruas da cidade do Rio de Janeiro" (Sigaud, 1835)
}

Ana Maria Galdini Raimundo 0 da

Os dois textos republicados na seção História da Psiquiatria deste número da Revista Latinoamericana de Psicopatologia Fundamental têm grande relevância, pois são dos primeiros que tratam da loucura como objeto científico, sendo muito citados pelos historiadores da medicina mental no Brasil. ${ }^{1}$

As perspectivas são diversas; o texto de Jobim é uma breve descrição de um caso atendido por ele, em termos de quadro clínico e de achados da necropsia, de um doente que sofria de "insânia"; já o de Sigaud, refere-se à defesa da criação de um estabelecimento próprio para o tratamento de doidos na Corte.

José Martins da Cruz Jobim (1802-1878), médico brasileiro formado em Paris, foi um dos fundadores da

1. No mesmo período, temos ainda a tese de graduação em medicina “Considerações gerais sobre a alienação mental” (1837), de Antonio Luiz da Silva Peixoto e "Importância e necessidade da criação de um manicômio ou estabelecimento especial para o tratamento dos alienados” (1839), de Luiz Vicente De-Simoni. Este último foi republicado na Revista Latinoamericana de Psicopatologia Fundamental, São Paulo, ano VII, n. 1, p. 142-59, mar./2004. 
primeira associação médica do país, a Sociedade de Medicina do Rio de Janeiro (SMRJ), em 1829, de cuja criação também participou José Francisco Xavier Sigaud (1796-1856), francês naturalizado brasileiro e médico do imperador Pedro II, que foi ainda editor de jornais médicos e autor de obras de medicina (Sacramento Blake, 1898).

O relato de caso de Jobim exemplifica uma prática médica que só se tornaria corrente no país bem mais tarde (no fim do século XIX), o exame do cadáver objetivando correlacionar o quadro clínico apresentado e alterações anatômicas patológicas eventualmente encontradas. Ali, já no título o autor se perguntava se a loucura agitada, com acentuada loquacidade, variações de humor e indícios de alucinações, seria ocasionada por uma grave afecção pulmonar, manifestada em vida e confirmada na necropsia.

O tratamento dado na Santa Casa aos doentes em geral, e aos loucos em particular, vinha sendo objeto de crítica dos médicos desde o início da década de 1830. O relatório de 1831 da Comissão de Salubridade da SMRJ, assinado pelo dr. Jobim, considerava as instalações do hospital insalubres, inadequadas e insuficientes para atender ao grande número de necessitados; sobretudo, eles consideravam o tratamento reservado aos loucos como sendo "o cúmulo da barbaridade” (Jobim et al., 1831, p. 79).

O artigo de Sigaud reflete, assim, a posição da Sociedade de Medicina, e visa dar publicidade à idéia de que o "tratamento dos maníacos” deveria sair da esfera da caridade e entrar para a da filantropia, entendida como ação do estado monárquico voltada para os pobres e dirigida segundo os preceitos da "higiene pública” e da "polícia médica”. Bem interessante ainda é a sua descrição de tipos de rua, loucos que circulavam pela cidade do Rio, bem como da reação da população a eles.

A SMRJ, transformada em órgão oficial, a Academia Imperial de Medicina (1835), prosseguiria em sua campanha pela criação de um hospício de alienados na Corte que, entretanto, só teria sucesso graças à ação incisiva do ministro imperial e provedor da Santa Casa José Clemente Pereira. Como sabemos, o Hospício Pedro II foi criado pelo imperador em 1841, ligado administrativamente à Irmandade da Misericórdia, e inaugurado em 1852 em magnífico edifício construído na Praia Vermelha. Ele daria início a uma nova fase na história da institucionalização dos alienados no Brasil (Oda e Dalgalarrondo, 2004).

Com a republicação destes e outros textos, os editores da seção pretendem oferecer aos leitores a oportunidade de tomarem contato direto com importantes fontes primárias que, em geral, tendem a ser do conhecimento apenas de alguns pesquisadores da área. 


\section{Referências}

Jobim, J. M. C.; Silva, J. J.; Santos, C. J. Relatório da Comissão de Salubridade Geral, da Sociedade de Medicina do Rio de Janeiro, apresentado e aprovado na sessão de 19 de junho (de 1830). Semanário de Saúde Pública, n. 15, p. 77-81, abr./1831.

Oda, A. M. G. R.; Dalgalarrondo, P. O início da assistência aos alienados no Brasil ou importância e necessidade de estudar a história da psiquiatria. Revista Latinoamericana de Psicopatologia Fundamental, São Paulo, ano VII, n. 1, p. 128-41, mar./2004. Sacramento Blake, A. V. A. Dicionário bibliográfico brasileiro. Rio de Janeiro: Imprensa Nacional, 1898. v. 4. 